\title{
Significance Of Life Skills Education
}

\author{
Ravindra Prajapati, Ph.D., Fiji National University, Fiji \\ Bosky Sharma, Fiji National University, Fiji \\ Dharmendra Sharma, Ph.D., Fiji National University, Fiji
}

\begin{abstract}
Adolescence is a period when the intellectual, physical, social, emotional and all the capabilities are very high, but, unfortunately, most of the adolescents are unable to utilize their potential to maximum due to various reasons. They face many emerging issues such as global warming, famines, poverty, suicide, population explosion as well as other issues like alcoholism, drug abuse, sexual abuse, smoking, juvenile delinquency, anti-social acts, etc. that have an adverse effect on them and others too, to a large extent. The cut-throat competition, unemployment, lack of job security, etc. are some of the major concerns for the educated and as a result, they are caught in the mad race. This new challenge requires immediate and effective responses from a socially responsible system of education. 'Education' is important, but education to support and live life better is more important. It has been felt that life skills education bridges the gap between basic functioning and capabilities. It strengthens the ability of an individual to meet the needs and demands of the present society and helps in dealing with the above issues in a manner to get desired behavior practical. Imparting life skill training through inculcating life skill education will help youth to overcome such difficulties in life.
\end{abstract}

The present paper focuses on the importance of life skills education and the benefits of imparting life skill education in our curriculum i.e. developing social, emotional \& thinking skills in students, as they are the important building blocks for a dynamic citizen, who can cope up with future challenges, and survive well.

Keywords: Life Skills Education; Adolescent; Challenges

\section{INTRODUCTION}

f $n$ the new millennium, education is undergoing a revolutionized change regarding science \& technology, globalization, privatization, urbanization, industrialization, etc. Today's youth are facing many emerging issues such as global warming, famines, poverty, suicide, population explosion as well
as social, emotional, physical and psychological issues. Cut-throat competition, unemployment, lack of job security, etc. are some of the major concerns for the educated and as a result, they are caught in the mad race. No one has time for his/her 'self', to develop empathy with surrounding and to have harmony in society.

Young mind is being considered, as the most productive members of the society, due to their physical and intellectual capability. But in real scenario, most of them are unable to utilize their potential in an appropriate way due to lack of guidance and motivation. Social problems like alcoholism, drug abuse, sexual abuse, smoking, juvenile delinquency, anti-social acts, etc. have an adverse effect on them and others too, to a large extent.

This new challenge requires immediate and an effective response from a socially responsible system of education. Education, now a days is hence, very important, but the kind of education, to support and live life better is more important. Thus, the cardinal focus of Education, therefore, needs an extraordinary emphasis on developing such skills in students, as they are the important building blocks for a dynamic citizen, who can cope up with future challenges, and survive.

Central Board of Secondary Education (CBSE) India has recognized this fact that it is necessary to develop scholastic as well as co-scholastic areas, and hence, has made life skill education as a compulsory element in its curriculum. It has been felt, that life skills education bridges the gap between basic functioning and capabilities. It 
strengthens the ability of an individual to meet the needs and demands of the present society. Thus, a relevant life skill education helps in dealing with the above issues in a manner to get desired behavior practical.

\section{REVIEW OF LITERATURE}

The topic has been a significant area of interest to the researchers, theorists, and practitioners, and there have been numerous researches carried out to emphasize the importance \& effectiveness of life skills education in the development of students' social, emotional and cognitive development \& dealing with their psychosocial problems and issues.

According to Albertyn et al. (2004) life skills training enhance critical thinking abilities, which further impacts were living life actively, being responsible in the job and in future planning too.

Ramesh and Farshad C. (2004) in his study proved the effectiveness of like skills training in increasing mental and physical health, pro-social behavior and decreasing in behavioral, social problems \& self-destructive behaviors.

Smith \& et al., (2004) noted significant improvement in interpersonal relationship and reduction in aggression and behavioral problems.

Tuttle et al., (2006), during their investigation, add the life skills to students' curriculum. The results of this study suggested the extraordinary capability of teens to positive promotion and flexibility.

Vranda and Rao (2011) proved that life skills training enhanced their psychosocial Competencies.

Puspakumarag (2013) in his study showed that life skills training was effective in preventing a wide range of problems such as substance abuse, teenage pregnancies, violence Bullying \& to promote self-confidence and selfesteem among the adolescents.

Roodbari, Sahdipoor, and Ghale (2013) in their research showed that life skills training has a positive effect and improves social development, emotional and social adjustment, suggesting an increase in compatibility of children and public health.

The present paper focuses on how enhancing social, emotional and thinking skills through life skills education, helps the 21 st- century youngsters to achieve their goals strengthens the abilities to meet the needs and demands of the present society and be successful in life.

\section{LIFE SKILL EDUCATION}

According to UNICEF, Life Skills are a behavior change or behavior development approach designed to address balance of three areas:

- $\quad$ Knowledge

- Attitude

- Skills.

The world bodies such as UNICEF, UNESCO, and WHO list the ten core Life Skills as:

1. Self-awareness

2. Critical thinking

3. Creative thinking

4. Decision making

5. Problem Solving
6. Effective communication

7. Interpersonal relationship

8. Empathy

9. Coping with stress

10. Coping with emotion 
Life skills training/ education takes into account psychosocial competencies and interpersonal skills that help students to take right decisions, solve problems, think critically and creatively, communicate effectively, build healthy relationships, empathize with others, and cope with managing their lives in a healthy and productive manner.

(WHO) defines Life skills as the abilities for adaptive and positive behavior that enable individuals to deal effectively with the demands and challenges of everyday life.

Life skill has been classified into three broad categories:

- Thinking skills: Thinking skills are the skill that enhances the logical faculty of the brain using an analytical ability, thinking creatively and critically, and developing problem-solving skills and improving decision-making abilities.

- Social skills: Social skills include interpersonal skills, communication skills, leadership skills, management skills, advocacy skills, co-operation and team building skills, etc.

- Emotional skills: Emotional skills, involves, knowing and being comfortable with oneself. Thus, selfmanagement, including managing/coping with feelings, emotions, stress and resisting peer and family pressure.

\section{Imparting ‘Life Skills Education’ In Classroom}

Imparting Life Skills Education in classroom has been researched meticulously. In the light of the above literature review, now have been a proven fact that it has positive outcome when taught as a part of curriculum Yadav P, Iqbal $\mathrm{N}$ (2009). There are various past research indications, over life skills be implemented as a training program, as an intervention approach and a model contributing to healthy development of adolescents. Thus, the significance of life skills education and in the following section researchers have tried to attempt, how with the help of simple activities it can be implemented in classroom settings. Different activities that can be used to enhance Life Skills in Students are as follows:

Classroom Discussions: An activity, providing opportunities for students to learn and practice turning to one another in solving problems. Enables students to deepen their understanding of the topic and personalize their connection to it. Develops skills, in listening, assertiveness, and empathy.

Brainstorming: It allows students to generate ideas quickly and spontaneously. Helps students use their imagination and think out of the box. Good discussion starter because the class can creatively generate ideas. It is essential to evaluate the pros and cons of each idea or rank ideas according to certain criteria.

Role Plays: Along with being a fun activity and involves whole class, to be active and participative, it also provides an excellent strategy for practicing skills; experiencing how one might handle a potential situation in real life; increasing empathy for others and their point of view; and increasing insight into own feelings.

Groups: Groups are helpful when the time is limited as it maximizes student input. Allows students interactions, allows to, know, one another better which in a way enhances team building and team work.

Educational Games and Simulations: It promotes fun, active learning, and rich discussion as participants work hard to prove their points or earn points. They require the combined use of knowledge, attitudes, and skills and allow students to test out assumptions and abilities in a relatively safe environment.

Analysis of Situation and Case Studies: It gives a chance, to analyze, explore, challenges, dilemmas and safely test solutions for; providing opportunities for working together in groups, sharing idea, new learnings and gives insight and promotes sometimes to see things differently.

Case studies are like powerful catalysts for thought and discussion. Engaging in this thinking process; students improve their own, critical thinking, decision-making skills. It also gives chance to confront with risks or any challenges and find ways to cope with it. 
Story-Telling: Can help students think about local problems and develop critical thinking skills, creative skills to write stories, or interact to tell stories. 'Story-Telling' lends itself to draw analogies or make comparisons, help discover healthy solutions. It also enhances attention, concentration, listening skills and develops patience and endurance.

Debates: Provides opportunity to address a particular issue in depth and creatively. Health issues lend themselves well: students can debate, for instance, whether smoking should be ban in public places in a community. It allows students to defend a position that may mean a lot to them. It offers a chance to practice higher thinking skills.

\section{DISCUSSION \& CONCLUSION}

A relevant and proper implementation of life skill education is a need of an hour, for today's society. Imparting life skills education to the students, can be helpful as it specifically addresses the needs of children, helps in motivating, providing practical, cognitive, emotional, social and self-management skills for life adjustments. Yadav P, Iqbal $\mathrm{N}(2009)$ showed positive results of imparting life skills education to students and bringing the change in adolescent' $\mathrm{s}$ attitude, thought and behavior by providing supportive environment to them.

According to Errecart et al., (1991) and Caplan et al., (1992) life skills education proves to be an effective approach in primary prevention education, as its more interactive, uses problem solving approach and is activities based. Hence, teacher and the taught both involves in learn and fun too.

On the whole, life skills education, have found to be an effective psychosocial intervention strategy for promoting positive social, and mental health of adolescents which plays an important role in all aspects such as strengthening coping strategies and developing self-confidence and emotional intelligence, as well as enhancing critical thinking, problem solving and decision making skills as has been well documented in the aforementioned studies. Thus, there is, significance and importance of life skills education to be integrated into the regular school curriculum and given on a daily basis by a life skills trainer/ teacher/counsellor to enhance the mental health of students, equip them with better adapted skills to face the challenges of changing life situations and empower them to become fully functioning contributors to the host society in particular and the world in general.

In the light of above discussion, it could be concluded, that, Life skill education has its importance and significance in overall development of students. Our findings are in common to the findings of Botvin, et al., (1998), Nair. M.K.C, (2005) many more, suggesting life skill education program as a good supportive system for adolescents.

Future Implications: Although considerable progress has been made in the past decade, and in the present study too, to reflect, life skills education, as an effective mode of education, which does enhances social, emotional and thinking skills, and helps the 21 st- century youngsters to achieve their goals, by strengthening their abilities to meet the needs and demands of the present society and be successful in life but still further empirical research is needed from future researchers, academicians and professionals in the related field to demonstrate robust findings.

\section{AUTHOR BIOGRAPHIES}

Dr. R.K. Prajapati, has done his Bachelors \& Masters in Psychology from M.D. University, Rohtak, Haryana, India. He completed his PhD- Psychology in 2011. He is presently working as a Clinical Psychologist, Empower Pacific, lautoka, Fiji. His work experiences mark his training and competence at both National \& International Organizations. He has also been involved in teaching, Training, research and consultancy. His research papers published in peer reviewed journals.

Dr. Dharmendra Sharma, has done his Bachelors \& Masters in Psychology from MLSU, Udaipur, Rajasthan, India. He completed his PhD- Psychology in 2013. He is presently working as a Counselor, Fiji National University, Suva, Fiji. His work experiences mark his training and competence at both National \& State Organizations. He has also been involved in teaching and research and has developed two psychometric scales and have published a book, wrote chapters in a book and have research papers published in peer reviewed journals. 
Ms. Bosky Sharma, holds a Bachelors \& Maters degree in Clinical Psychology and is a Post Graduate Diploma in Clinical \& Applied Hypnotherapy 2010. She completed her Bachelors in Education in 2012. Currently, she is affiliated with Fiji National University, Suva, Fiji, as a Counselor. She has acquired excellent training and practical exposure for counselling \& teaching Psychology at Secondary \& Tertiary Level. Along with her inclination and passion towards research she has published a book, few chapters in book and done research paper publications too in peer reviewed journals.

\section{REFERRENCES}

Botvin, G., Griffin, K., Paul, E., \& Macaulay, A. (2003). Preventing Tobacco and Alcohol Use Among Elementary School Students Through Life Skills Training. Journal of Child \& Adolescent Substance Abuse, 12(4), 1-17. http://dx.doi.org/10.1300/j029v12n04_01

Clark, D. (1995). Bloom's Taxonomy of Learning Domains: The Cognitive Domain. Nwlink.com. Retrieved 14 December 2015 , from http://www.nwlink.com/ donclark/hrd/bloom.html

Nair, M. (2005). Family Life \& Life Skills Education for Adolescents. Abstract, University of Southampton.

Pillai, R. (2012). The importance of life skills education for children and adolescents. Mind the young minds. Retrieved from https://sites.google.com/site/mindtheyoungminds/souvenir-cum-scientific-update

Puspakumara, J. (2011). Effectiveness of life-skills training program in preventing common issues among adolescents: a community based quasi experimental study (ALST). Presentation, Dept. of Psychiatry Faculty of Medicine \& Allied Sciences Rajarata University of Sri Lanka.

R M, A., CA, K., \& CJ, C. (2001). Patterns of empowerment in individuals through the course of a life-skills programme in South Africa. Ingentaconnect.com. Retrieved 13 December 2015, from http://www.ingentaconnect.com/

Ramesht, M., \& Farshad, C. (2006). Study of life skills training in prevention of drug abuse in students. Lecture, The 3rd Seminar of Students Mental Health; Iran University of Science and Technology; Persian.

Roodbari, Z., Sahdipoor, E., \& Ghale, S. (2013). The Study of the Effect of Life Skill Training On Social Development, Emotional And Social Compatibility Among First- Grade Female High School In Neka City. Indian Journal of Fundamental and Applied Life Sciences, Vol. 3(3), 382-390. Retrieved from http://www.cibtech.org/jls.htm

Smith, E., Swisher, J., Hopkins, A., \& Elek, E. (2006). Results of a 3-Year Study of Two Methods of Delivery of Life Skills Training. Health Education \& Behavior, 33(3), 325-339. http://dx.doi.org/10.1177/1090198105285020

Tuttle, J., Campbell-Heider, N., \& David, T. (2006). Positive Adolescent Life Skills Training for High-Risk Teens: Results of a Group Intervention Study. Journal of Pediatric Health Care, 20(3), 184-191. http://dx.doi.org/10.1016/j.pedhc.2005.10.011

Vranda, M., \& Rao, M. (2011). Life Skills Education for Young Adolescents and Indian Experience. Journal of The Indian Academy of Applied Psychology, 37(Special Issue), 9-15. Retrieved from http://repository.um.edu.my/18138/1/jiaap\%20halim\%20santosh\%202011.pdf

Yadav P, Iqbal N (2009). Impact of Life Skill Training on Self-esteem, Adjustment and Empathy among Adolescents. Journal of the Indian Academy of Applied Psychology, (35) Special Issue, 61-70. Retrieved from http://medind.nic.in/jak/t09/s1/jakt09s1p61.pdf

Yankey T, Biswas U.N (2012). Life Skills Training as an Effective Intervention Strategy to Reduce Stress among Tibetan Refugee Adolescents. Journal of Refugee Studies. 25(4). doi:10.1093/jrs/fer056 


\section{NOTES}

